\section{Antecedents of a Nobel prize}

SIR-The award of the 1989 Nobel Prize in Medicine and Physiology to Drs $J$. Michael Bishop and Harold E. Varmus has ended up in a controversy raised by $\mathrm{Dr}$ Dominique Stéhelin. As an author of one of the two papers and one who worked for the first six months on this project, I am well placed to describe the events leading to that masterpiece work. I record here the relevant chronology as I know it so that the scientific community can judge that the prize was properly awarded.

I joined Bishop's laboratory on 4 January 1973 as an assistant research microbiologist. Stéhelin had preceded me by a few months and was working on characterizing polysome-associated virusspecific mRNA. Very soon, Stéhelin and I became close friends and began to exchange views on a variety of issues, ranging from science to politics. He was somewhat frustrated because his project was not going well and because of personal problems.

Before joining the laboratory, I had set my mind on working on the various DNA intermediates in retrovirus-infected virus cells because of the spectacular discovery of reverse transcriptase by Mizutani and Temin, and by Baltimore, in 1970 (Mizutani did not get the prize, Temin did). When I arrived in the laboratory, Bishop suggested that I should talk to all the postdoctoral fellows and technicians to familiarize myself with various projects. After several discussions, I made up my mind to work on DNA intermediates, as nobody else was actively pursuing that topic. Varmus himself was working on integration by network formation followed by reassociation kinetics. He advised me on various tissue culture and molecular biology techniques, and Nancy Quintrell, a research assistant, provided me with valuable information on preparing probes and so on.

After a week, I had a meeting with Bishop and Varmus, at which Varmus suggested that I should first start by preparing the src probe. He outlined the rationale, which was based on the original observation by Peter Duesberg and Peter Vogt that transformation-defective variants lack a sequence of about 1,000 to 1,500 nucleotides. It sounded to me very interesting and I therefore set out to do the experiments.

I prepared radiolabelled cDNA probes from wild-type virus and hybridized them to the 70S RNA from transformationdefective (td) virus. I began to notice differences in the extent of hybridization between them and therefore pursued this observation vigorously for three or four months. As my heart was set on doing experiments with viral DNA intermediates, I began those experiments simultaneously. In about two or three months, I obtained evidence that the first steps of reverse transcription occur in the cytoplasm. We were all excited by what seemed to be a seminal observation, but I had to prove that the DNA we detected in the cytoplasm was not due to leakage from nucleii. After these initial observations, Varmus started enucleating the cells to show conclusively that DNA synthesis occurs in the cytoplasm.

In the next few months, we concentrated on this project, which resulted by the end of 1973 in the discovery of supercoiled DNA. As a result of this diversion, I had to slow down the work on $s r c$, and was only occasionally able to work on that project. One day in July 1973, Bishop came to me and said, "Ram, since your project on DNA synthesis is going so well, do you mind if Dominique continues this project; but I want to assure you that you are part of this project as well".

I readily accepted the proposal, since Stéhelin was (and is) a good friend, and his original project was not going well. I handed over my notebook to Stéhelin. He started working on this project at the end of July or August 1973, while I pursued the studies on DNA intermediates. By the end of 1973, we found supercoiled DNA, and the work on this was presented in 1974 at a symposium held at Rutgers University and at the Cold Spring Harbor meeting and later published in Nature in 1975.

I continued to attend the weekly meetings with Bishop, Varmus and Stéhelin until the middle of 1974 , but discontinued later because of my own projects and also because of my intensive effort at job hunting. Stéhelin worked hard, and successfully prepared the $s r c$ probe. Once the probe was defined, it was logical to evaluate it on all the DNAs available.

In my view, Bishop and Varmus deserve the Nobel prize. Several others such as Peter Duesberg, Peter Vogt, H. Hanafusa, Jeff Cooper and R. A. Weinberg could have been included, because the first three laid down fundamental work which made possible the oncogene work on retroviruses and the last two contributed to identifying cellular oncogenes not present in retroviruses.

In retrospect, it seems to me that if I had not obtained positive results, there would have been no oncogene project. In many laboratories, many students and research fellows begin work on new projects, but not many succeed. Initial failure of any project results, in general, in its abandonment. Very few continue on a project when several experiments fail. That was what happened to Stéhelin's first project and therefore, to my mind, fortuitous circumstances paved the way for his involvement in the oncogene project.

Therefore, as the first participant in the early work, in the 1970 s, which led to the award of the 1989 prize, I believe that the Nobel committee acted prudently in the selection of Bishop and Varmus. I hope that the Nobel committees will continue to base their decisions on scientific merit, ingenuity and the impact of discoveries and ignore the publicity and politics which develop following some discoveries, such as that of the AIDS virus, which is but one among many such discoveries and controversies of the past decade.

RAMAREDDY V. GUNTAKA Department of Molecular Microbiology and Immunology, University of Missouri-Columbia, Columbia, Missouri 65212, USA

SIR-Under the heading "Conduct unbecoming", Nature 1 says that "As all agree, Stéhelin was the main pair of hands behind the experiments that first showed that the oncogenes of tumour viruses are stolen and corrupted versions of genes from the cells. ..". The latter half of this statement is incorrect for the following reasons.

The first demonstration of the cellular origin of viral oncogenes was published from entirely different laboratories three years before the paper by Stéhelin et al. ${ }^{2}$ appeared in 1976. Scolnick et al. ${ }^{10}$, cited in Stéhelin et al.'s 1976 paper, and Tsuchida, Gilden and Hatanaka ${ }^{4}$ observed in 1973 and 1974 respectively that the ras sequences, then called src, of Harvey and Kirsten sarcoma viruses were from cellular genes. The title of a paper by Scolnick and Parks in 1974 is "A second murine Type $\mathrm{C}$ virus with rat genetic information" ${ }^{3}$ and that of a paper by Tsuchida, Gilden and Hatanaka is "Sarcoma virus related RNA sequences in normal rat cells" ${ }^{4}$. The protocol of these experiments was exactly the same as that used later by Stéhelin et al. and so was the conceptual basis, namely to test Huebner's and Todaro's oncogene hypothesis of $1969^{5}$ with the then newly discovered viral oncogenes. The oncogene hypothesis postulated the existence of switched-off cancer genes in normal cells. The only technical distinction between the original experiments with the Harvey and Kirsten viruses and the later ones by Stéhelin et al. with the Rous sarcoma virus was that, in addition to sequences from the cell, the Harvey and Kirsten viruses had also 'stolen' sequences from an endogenous rat retrovirus. This was painstakingly and convincingly sorted out by the Scolnick group in subsequent years.

Further, there is no mention in Stéhelin et al's paper ${ }^{2}$ that the sequences transduced had been 'corrupted' cellular sequences. Instead, these sequences were called viral homologs of cellular genes in this $^{2}$ and subsequent studies ${ }^{6}$. Indeed, on the basis of this homology, the cellular progenitors of viral onc genes were proposed to be switched-off cellular 